\title{
OS ENIGMAS DO AMOR: RECEPÇÃO E TRADUÇÃO DOS SONETOS DE SHAKESPEARE NA PONTE INGLATERRA-BRASIL
}

\section{Gisele Dionisio da Silva*}

RESUMO: Este artigo enfoca os Sonetos do poeta e dramaturgo inglês William Shakespeare, obra lírica que têm suscitado curiosidade e polêmica de público e de crítica desde sua publicação primeira em 1609, em virtude das diversas controvérsias que norteiam sua temática. Buscamos averiguar como tais controvérsias moldaram a recepção pública da obra na Inglaterra e, em especial, no Brasil, onde a iniciativa dos tradutores em vertê-la para a lingua portuguesa e o interesse da crítica local ocorreram um tanto tímida e tardiamente, se comparada às obras dramatúrgicas do bardo inglês. Portanto, com vistas a exemplificar como tradutores brasileiros lidam com tais controvérsias, será apresentada uma breve análise comparativa do Soneto 144 e de quatro releituras em lingua portuguesa ([1957]; 1969; [1970]; 1994).

UNITERMOS: tradução de poesia; recepção; soneto; William Shakespeare; soneto 144.

ABSTRACT: This article focuses on the Sonnets, written by the English playwright and poet William Shakespeare. Due to the many controversies surrounding their themes, this lyrical work has stirred the curiosity and polemics among the public and the critics since its first publication in 1609. This article intends to verify how such controversies have shaped the public reception of the Sonnets in England and especially in Brazil, where the translators' initiative of rendering them into Portuguese, as well as the interest of local

* UFG. 
critics, occured timidly at a rather late stage in comparison with Shakespeare's plays. In order to exemplify how Brazilian translators deal with such controversies, a brief contrastive analysis of sonnet 144 and four Portuguese re-readings will be presented ([1957]; 1969; [1970]; 1994).

KEYWORDS: poetry translation, reception, sonnet, William Shakespeare, sonnet 144.

\section{Introdução: o dramaturgo e a escrita de sonetos}

O nome de William Shakespeare sempre esteve mais ligado à dramaturgia, sendo suas peças - em especial as tragédias, protagonizadas por personagens conflituosas e passionais - intensamente aclamadas até a atualidade por suas conotações político-culturais e pelas reflexões tecidas em torno de sentimentos e emoções tão humanos. Contudo, a extrema habilidade lingüística de Shakespeare e a variedade de seus recursos estéticos o conduziram, a partir de 1590 , ao exercício de um outro gênero literário então em voga entre os poetas elizabetanos: sonneteering, ou a escrita de sonetos (Heliodora, 1997). Fontes documentadas sugerem que Shakespeare, proibido de atuar em razão dos surtos de peste que obrigaram o fechamento dos teatros londrinos, voltou-se para a composição e revisão de seus sonetos, com vistas a uma recompensa de um mecenas da corte (Duncan-Jones, 1997, p. 8), ${ }^{1}$ cuja publicação era continuamente adiada devido à reabertura dos teatros. Seus sonetos, já referidos em 1598 por Francis Meres (citado em Duncan-Jones, 1997, p. 1) como açucarados, finalmente vieram a público, em número de 154, no ano de 1609, graças ao trabalho do editor Thomas Thorpe.

A atitude de Shakespeare em relação à escrita de sonetos é sem dúvida interessante, pois, no âmbito de várias de suas peças, ele faz diversas alusões ridicularizadoras à produção de poemas amorosos em geral, e aos sonetos melosos, repetitivos e

1 Todas as citações extraídas de textos em língua inglesa são traduções minhas. 
previsíveis em particular. Então, em virtude da indagação da razão que conduziu o dramaturgo a compor uma seqüência de sonetos tão longa, não obstante sua aversão a poemas estritamente sentimentais, uma possibilidade forte consistiria em considerar uma motivação de cunho literário; Duncan-Jones (1997, p. 49) afirma que o poeta "buscou apropriar e redefinir o gênero, rejeitando os velhos conceitos de devoção à amada, e criar uma seqüencia de sonetos tão diferente de todos seus predecessores que a forma nunca poderia voltar a ser a mesma". ${ }^{2}$

A fim de atingir tal intento, Shakespeare tentou conceber um tipo de soneto estruturalmente convencional porém tematicamente diferente do estilo petrarquiano, então soberano na produção do continente (e também da Inglaterra) há mais de duzentos anos. O bardo inglês vai no contrafluxo da poesia de Petrarca e Sidney e propõe um objeto amoroso masculino (não feminino, como ditavam a tradição e a moral), personificado por um jovem real e provido de defeitos em vez de uma mulher distante, idealizada e inacessivel. Nesse esteio, o poeta distancia-se do tema de amor secular rumo à transcendência religiosa e promove a descrição de um amor carnal pela 'dama morena', o qual, longe de aspirar a uma completude espiritual, objetiva apenas a consumação do desejo.

Desde a publicação em 1609, o mistério acerca das figuras centrais dos Sonetos tem crescido em intensidade. A indagação, que partiu com mais freqüência de críticos e leitores em geral, refere-se à natureza biográfica ou ficcional que motivou a delineação do 'belo jovem', da 'dama morena' e, em menor grau, do 'poeta rival'. Tal ânsia por verificar a existência histórica dessas personagens vincula-se à crença de que os Sonetos não constituiriam uma produção ficcionalizada shakesperiana como as peças dramatúrgicas, mas configurar-se-iam como resultado de uma experiência viva do poeta: nesse esteio, "alguém já disse que se Shakespeare tivesse inventado o de que tratam os sone-

2 Ainda segundo Duncan-Jones (1997), a alternativa de uma motivação de natureza pessoal é preferida por críticos românticos, os quais apontam para alguma experiência de vida do poeta (um caso amoroso frustrado, por exemplo) que o tenha instigado à atividade sonetista. 
tos, teria inventado algo melhor" (Wanderley, 1994, p. 17). Munidos dessa concepção, muitos daqueles que se debruçam sobre os Sonetos geralmente o fazem com vistas ao deciframento de enigmas que escamoteiam algum fato ou figura verídica, relegando a segundo plano a apreciação estritamente estético-literária da seqüência poética.

No entanto, torna-se possivel dizer que as personagensenigmas dos Sonetos - independentemente de sua consideração como pessoas reais, criações imaginárias ou alegorias de emoções ou situações caras ao poeta - são vistas comumente pela crítica como satélites orbitando em torno do que é considerado o lado mais inquietante da obra em pauta: a faceta possivelmente homossexual do Poeta Nacional da Inglaterra. Apesar de que a principal tendência da crítica contemporânea seja resistir à insistente tentação de estabelecer paralelismo direto entre os sentimentos (eles mesmos ambíguos) delineados nos Sonetos e a personalidade do homem Shakespeare, as implicações homossexuais vislumbradas na adoração ao 'belo jovem' e no desprezo satírico à 'dama morena' ainda provocam repercussões nos defensores do status shakesperiano. Segundo Shepherd (1988, p. 97), "a tarefa da critica é descobrir uma sexualidade adequada para o bardo nacional", condizente com os interesses morais e culturais que o país deseja transmitir ao resto do mundo. A publicação dos Sonetos instaurou uma dúvida quanto a esse aspecto polêmico, o que, de certa forma, comprometeu sua recepção perante o público elizabetano, como será exposto a seguir.

\section{Recepção e critica: da era elizabetana à atualidade}

Todo falante encontra-se inserido numa comunidade que, por meio de instituições de diversas espécies, estabelece concepções e normas responsáveis pela identidade do grupo. Desse modo, o crítico norte-americano Fish (1980) formulou, em extensão às comunidades lingüísticas já vislumbradas pelas pesquisas estruturalistas, o conceito de "comunidade interpretativa", tida como "uma estrutura de normas" (Fish, 1980, p. 318) pautada "numa base comum de acordo" (p. 317), a qual direciona 
e limita a interpretação dos indivíduos mediante os significados convencional e socialmente adotados. São as comunidades interpretativas espalhadas no tempo e no espaço que se encarregam de postular os critérios de aceitabilidade e avaliação de dado escritor e sua obra, os quais se refletem nas expectativas mantidas pelo público-leitor e nas possibilidades de leituras e interpretações vislumbradas pela crítica em voga.

Esse processo é observado com clareza no caso de Shakespeare - em que há infindáveis especulações sobre a veracidade de seus dados biográficos e de sua autoria - pois, segundo Vollet (1998, p. 75), "[n]ão passaria de precária e vã qualquer tentativa de estabelecer uma face de Shakespeare que tenha atravessado os tempos com feições absolutamente imutáveis”. De bárbaro a gênio, o bardo inglês tem sido considerado e assimilado pelas comunidades de modos discrepantes, cujas imagens alternamse "à medida que correspondiam ao gosto e valores de cada época ou os desafiavam” (Vollet, 1998, p. 75).

Todavia, o discurso dominante construído em torno da figura do bardo inglês ${ }^{3}$ tem continuamente atribuído a ele uma aura de elitismo e erudição, a qual seria acessivel apenas àqueles providos de intelectualidade e nobreza que constituíssem a fina flor do suposto público-alvo das complexas reflexões do poeta. A construção dessa imagem de Shakespeare se deve, em grande parte, à barreira erigida pela própria língua inglesa, pois as modificações ocorridas com o decorrer de cinco séculos têm distanciado cada vez mais os leitores atuais da variedade lingüística corrente no período elizabetano. Devido a essa difundida incompreensibilidade, Shakespeare surge como detentor de uma superioridade lingüístico-intelectual que precisa ser 'traduzida' ao público por um grupo restrito de eruditos, o que freqüentemente mascara o fato de que a linguagem utilizada pelo poeta espelha conjunturas lingüisticas especificas, não devendo servir de critério para uma intelectualidade atemporal.

3 Holderness (1988) apresenta uma interessante reflexão acerca do fenômeno de devoção semi-religiosa apresentada pelos admiradores de Shakespeare (personificada em especial pelas levas de turistas a Stratford), fenômeno por ele denominado de 'bardolatria'. 
Não obstante às oscilações trazidas à tona pelas diversas comunidades interpretativas existentes entre a era elizabetana e os tempos atuais, subjaz uma tendência constante da crítica de rotular Shakespeare como um gênio transcendental, em especial a partir da constituição da literatura enquanto disciplina (Eagleton, 2001) e da instituição do cânone literário no século XIX - no qual, dada a motivação imperialista da Inglaterra vitoriana e de sua língua, lhe caberia sempre um lugar assegurado. Vollet atesta essa questão (1998, p. 82):

A história oficial sobre Shakespeare, construída pelos críticos eruditos, divulgada e autorizada por instituições influentes e prestigiadas, foi, durante um longo período, praticamente o único determinante do entendimento de Shakespeare para a comunidade alvo desse discurso. [...] Sendo assim, a imagem fina e nobre de Shakespeare revela, antes de mais nada, a sua procedência, na medida em que reflete a ideologia, os interesses, a história de um determinado grupo cultural em sua localização temporal e de acordo com as mais diversas circunstâncias: sociais, políticas, econômicas, ideológicas.

Ainda segundo Vollet, em contraposição ao discurso dominante, que atenta apenas para "os aspectos de sua obra ou biografia dignos de atenção” (Vollet, 1998, p. 82) e os insere no universo acadêmico - oferecendo ao grande público somente uma visão distorcida, vaga e conveniente a certos interesses -, surge atualmente um discurso minoritário que visa à recontextualização histórica do Poeta Nacional da Inglaterra, por meio de um processo de desmitificação o qual reconsidera, também, a imagem idealizada de seu público-alvo. Assim, há uma tendência corrente que defende que, longe de apresentar suas peças para uma platéia eminentemente refinada, o bardo "foi um autor popular [...] que escreveu para um público eclético [...] - público esse que abrangia todo o espectro do mundo elizabetano"(Heliodora, 1997, p. xx). Em relação a esse processo desmitificador, vislumbrado pela estrutura de normas adotada pela comunidade interpretativa vigente, Holderness (1988, p. 13) comenta: 
Quando desconstruímos o mito de Shakespeare, o que descobrimos não é um gênio individual universal a criar textos literários que continuam sendo um depósito permanentemente valioso de experiência humana e sabedoria; mas um processo cultural colaborativo [...].

Esse processo cultural colaborativo resume-se justamente na consolidação dos significados que norteiam Shakespeare como uma construção sociocultural e histórica, não como um produto acabado e inalterável da coletividade.

O in quarto, de 1609, foi alvo de uma fria e silenciosa recepção na época de sua publicação, não obstante o status de celebridade já alcançado por William Shakespeare nesse período. As esparsas menções referentes à obra em pauta evidenciam que os leitores devem ter considerado os Sonetos chocantes ou decepcionantes, reação que propiciou a não-adesão de seus temas polêmicos por parte dos jovens poetas de então, os quais voltaram-se "para os temas devotos que Shakespeare havia neglicenciado tão visivelmente” (Duncan-Jones, 1997, p. 70). Com o passar dos séculos, tanto críticos quanto escritores renomados intensificaram a hostilidade aos Sonetos e suas duvidosas implicações e, quando não se ocupavam em esboçar indignação e repúdio ante o aspecto homoerótico da obra, tendiam a reorganizar os poemas ou mesmo atribuir sua motivação inspiradora a uma misteriosa mulher, retratada como a 'dama morena', com o intuito central de heterossexualizar os Sonetos.

Segundo Duncan-Jones (1997), até o fim do século XIX, qualquer interpretação atribuída aos poemas shakesperianos era comumente vista como decorrente da personalidade e sexualidade do crítico que a propusesse, fato que inibiu as leituras homoeróticas críticas e apenas as tornou mais aceitáveis após os atos parlamentares de 1967 na Inglaterra, os quais retiraram o caráter criminoso de relações homossexuais. Além disso, o fator cultural constituiu fundamental importância para a defesa da heterossexualidade do bardo inglês, pois a vida e a obra de Shakespeare sempre foram consideradas propriedade nacional e, como tal, deveriam refletir o que há de melhor e mais elevado 
na cultura inglesa, como atesta Shepherd (1988, p. 99, grifo do autor) $:^{4}$

A vida pessoal de Shagspair deve ser mantida separada, pois ela se tornou propriedade cultural nacional e, como modelo biográfico, reforça suposições sobre sexualidade. Escreve-se freqüentemente sobre sua vida como se não fosse um produto da história mas a transcendesse, visto que deve ser reconhecivel à sociedade de agora. Shackespieare tem que ser visto como um de nós. Não um deles (marginais, criminosos, homossexuais, desordeiros). Portanto a vida sexual deve ser mantida em ordem.

Assim, a Inglaterra não poderia apresentar ao mundo um Shakespeare polemizado, o qual, como instrumento hegemônico de uma determinada ideologia, ameaçasse "uma noção elitista de cultura e uma visão de mundo de classe dominante" (Margolies, 1988 , p. 43). Portanto, caberia à crítica perpetuar a imagem moralmente inquestionável da Inglaterra representada por seu poeta nacional, e essa tarefa inicialmente literária adquiriu rapidamente um cunho eminentemente político, assim delineado por Shepherd (1988, p. 100): "Alistar o bardo para o liberalismo faz parte do processo de retratá-lo como um gênio universal, capaz de escrever sobre todo tipo de esquisitices com maestria." Essa ânsia pela universalidade do cânone literário requer a omissão de fatores histórico-sociais que confirmem certas tendências e motivações sexuais, pois, como complementa Shepherd (1988, p. 100), o liberalismo "precisa empregar uma definição ahistórica de esquisitice homossexual antes de estender sua compaixão".

No entanto, já no século XX, Duncan-Jones (1997) constata que a tendência da crítica moderna consiste em desvincular Shakespeare do eu-lírico, atribuindo sua ousadia a motivos de inovação literária. Haveria ainda a hipótese de considerar a significação do vocábulo lover, tão recorrente nas exortações ao

4 Shepherd (1988) apresenta em seu texto diversas variações ortográficas do nome 'Shakespeare', duas das quais transcrevo aqui. 
'belo jovem', não apenas como 'amante', mas também como 'amigo', segundo o uso no período elizabetano (Mendes, 1969). Com o surgimento da Nova Crítica durante a década de 1930, tornou-se possivel uma apreciação mais favorável dos Sonetos devido ao uso de técnicas de leitura analítica (close reading) que, ao serem descontextualizadas, dificultam a associação com referências biográficas. Outro aspecto positivo foi o advento de diversos e importantes trabalhos críticos sobre a obra em questão realizados por mulheres, o que raramente acontecia antes do século XX. De acordo com Duncan-Jones (1997, p. 83) - ela mesma uma renomada pesquisadora do assunto -, "as leitoras são capazes de permanecer, simultaneamente, como calmas observadoras e emocionalmente receptivas ao impulso homoerótico dos poemas 1-126, o qual tem causado tanto aborrecimento a gerações de leitores".

Torna-se possivel afirmar, então, que as implicações sexuais contidas nos Sonetos tenham sempre inspirado suspeitas e desconforto em leitores e críticos (em especial nos homens) devido ao fato de que essa obra lírica shakesperiana não é associada a um mundo ficcional, como as peças, e sim vinculada aos sentimentos supostamente reais do poeta. Tal polêmica provocou, durante séculos, uma recepção de constrangimento em face dos poemas ao 'belo jovem', o que suscitou a condenação pública da obra ou, simplesmente, o mascaramento por parte daqueles que a admiravam. A insistência acerca do aspecto homoerótico, a necessidade de apontar figuras verídicas que se enquadrassem nas descrições de Shakespeare constituem, para Shepherd (1988, p. 105), uma tendência quase irresistível da obra, pois "[o]s comentários sobre os Sonetos são fascinados pelo mesmo espectro que tentam exorcizar".

O teor dessa recepção - moldada a partir das imagens que os ingleses possuem de seu bardo nacional - exerceu certa influência sobre a maneira como o mito shakesperiano abarcou, um tanto tardiamente, no Brasil, influenciando as concepções de críticos, dramaturgos e tradutores engajados em conhecer e transmitir sua obra ao grande público. A tônica da recepção shakesperiana em nosso país, instaurada também pelas particularidades de nossas próprias comunidades interpretativas espalhadas no tempo, será brevemente analisada a seguir. 


\section{Os Sonetos no Brasil}

William Shakespeare chegou ao Brasil em meados do século XIX, por meio de diversas adaptações de seu teatro nas línguas francesa, espanhola e portuguesa, visto que o inglês era conhecido apenas por um grupo extremamente restrito de pessoas. Isso ajudou a construir uma aura de inacessibilidade e erudição em torno dos trabalhos do bardo inglês. Com o início do século XX, começaram a surgir as primeiras traduções propriamente brasileiras das peças shakesperianas - como a de Carlos Alberto Nunes pela Editora Melhoramentos, a qual abarca todo o teatro shakespeariano (Gomes, [1961], p. 32). ${ }^{5}$ Nesse esteio, segundo Eugênio Gomes ([1961], p. 31), "[u]m fato curioso, mas lógico e compreensivel, é que, no Brasil, são os poetas que mais têm traduzido Shakespeare", afirmação que implica a crença de Gomes e de vários outros, relativa ao fato de que um tradutor que não fosse também poeta não saberia 'transpor' a verve poética de Shakespeare ao âmbito da língua portuguesa.

As traduções produzidas oferecem pistas acerca da natureza da recepção do autor em pauta em nosso país e, ainda segundo Gomes ([1961], p. 36), o Brasil seria um lugar propício para uma recepção positiva da obra shakesperiana, em face de sua imaturidade nacionalista e também literária do início do século XIX, como atesta o seguinte trecho:

País novo e exuberante, com problemas de afirmação vital em cujo vértice até o idioma estava fadado a passar por muitas experiências mais ou menos drásticas, a nossa condição, numa fase ainda trepidante de formação política da nacionalidade, era de natureza a assimilar melhor do que nunca o mais típico dramaturgo da época elizabetiana.

A imagem de Shakespeare em nosso território, imbuída de refinamento e nobreza (por associação à própria Inglaterra dos

5 Todos os trechos de Gomes [1961] aqui utilizados foram atualizados ortograficamente. 
tempos da rainha Elizabeth I), influenciou fortemente a concepção dos tradutores envolvidos com sua produção, pois, como ressalta Vollet (1998, p. 76-77), ao ponto de vista elitista "adequam-se, em sua maioria, as traduções brasileiras, que são eruditas e complexas, dificeis de serem lidas, acabando por excluir uma determinada parcela do público leitor”. As próprias circunstâncias em que a obra aqui abarcou - norteada por um acesso restrito aos poucos que sabiam ler em português ou em outras línguas - provavelmente contribuíram para a formação de traduções repletas de recursos lingüísticos rebuscados e complexos, transmitidas ao público brasileiro com o rótulo proposital de textos inacessiveis à maioria.

Essa imagem coloca Shakespeare e a Inglaterra num patamar cultural superior ao panorama brasileiro, ou seja, por meio dela "forma-se um pressuposto cultural implicito e explícito de que tudo que se relaciona a ele deve representar os supostos valores elevados da cultura" (Vollet, 1998, p. 77). Com isso, em virtude da idéia de uma platéia idealizada e erudita nos tempos elizabetanos, surge a crença de que os leitores brasileiros de hoje que se debruçarem (com sucesso) sobre as obras do bardo, também obterão o privilégio de se encontrarem imersos no nível restrito da cultura elitista. Junqueira (1991, ${ }^{6}$ grifos meus) esboça essa opinião no início de seu artigo Shakespeare em sonetos: "O leitor brasileiro, a quem amiúde se nega a possibilidade de freqüentar os grandes textos da literatura ocidental em virtude de seu pouco convivio com outras linguas, torna-se às vezes um privilegiado."

Em face da relativamente larga repercussão das peças teatrais do poeta inglês, como Hamlet, Macbeth e Romeu e Julieta, os Sonetos levaram mais tempo para serem traduzidos em língua portuguesa, o que corrobora a hipótese de que a natureza polêmica acerca dessa seqüência poética possa ter comprometido, de maneira análoga à Inglaterra, sua recepção pública no

6 A resenha crítica de Junqueira (1991) foi obtida através de serviço prestado pelo Banco de Dados da Folha de S. Paulo. No entanto, como esse texto foi publicado pelo jornal $O$ Globo, não foi possível ao Banco de Dados fornecer-me o número das páginas. 
Brasil. As implicações sexuais dos Sonetos podem ter abalado a visão do bardo como um escritor elitizado e provido de gosto impecável, fato que possivelmente inibiu a iniciativa e o interesse de tradutores do início do século XX.

Até o presente momento, não foram encontradas traduções brasileiras dos Sonetos anteriores a 1952 e 1953, quando Samuel Mac-Dowell Filho e Péricles Eugênio da Silva Ramos apresentaram suas releituras de 84 e 33 sonetos, ${ }^{7}$ respectivamente (Gueiros, 1975); esse dado revela, em si, uma tímida recepção tradutória no Brasil da obra em pauta. Todas as traduções conhecidas - há uma extensa lista reunida em Gueiros (1975), abrangendo produções de escritores renomados ou desconhecidos do grande público - foram produzidas no século XX, fragmentadas ou completas, e veiculam diversas escolhas decorrentes das concepções próprias dos tradutores relativas a aspectos lingüísticos e literários.

De maneira análoga, os críticos brasileiros não têm se debruçado, com freqüência, sobre as indagações amorosas trazidas pelos Sonetos nem sobre as traduções existentes em nossa língua, atendo-se com maior intensidade à análise de traduções das peças teatrais do bardo. As escassas análises da crítica brasileira geralmente limitam-se a breves resenhas publicadas em jornais, norteadas pelo pouco aprofundamento em torno das controvérsias peculiares às personagens dos Sonetos (nem mesmo a partir da perspectiva dos tradutores) e pela emissão de implacáveis juízos de valor. Esse julgamento é guiado pelo conceito de equivalência o qual permite aos críticos a priorização de traduções que possuem maior similitude com a estrutura do texto estrangeiro.

Dessa forma, com vistas a observar como tradutores brasileiros se deparam com as polêmicas trazidas à tona pelos Sonetos após séculos de especulações, optamos por analisar quatro traduções do Soneto 144, produzidas em momentos históricos e lingüísticos discrepantes. Selecionamos a tradução de Jerônimo de Aquino ([1957]), a qual não é contemplada em nenhum dos

7 Ramos ([1970]) amplia esse número para 45 poemas na segunda edição dos Sonetos. 
textos críticos encontrados, sendo, porém, ocasionalmente aludida por outros tradutores. Há a produção de Oscar Mendes (1969), um célebre tradutor que realizou traduções de toda a obra lírica de Shakespeare - incluindo as partes líricas presentes nas peças teatrais do bardo (Mendes, 1969). Na seqüência está o texto supracitado de Péricles E. da Silva Ramos ([1970]), possivelmente a mais conhecida dentre as traduções existentes no Brasil, devido ao renome de Ramos enquanto poeta vinculado à Geração de 45. ${ }^{8}$ Por fim, optamos pela tradução do ex-professor da UERJ, Jorge Wanderley (1994), a mais recente dentre as produções encontradas. Em seguida, apresento a análise comparativa proposta (as traduções analisadas aparecem em ordem cronológica, baseada na data das edições utilizadas).

\section{O maniqueísmo e o amor: análise do Soneto 144}

Eis o Soneto 144 (Shakespeare, 1997, p. 403), objeto de estudo desta análise:

Two loves I have, of comfort and despair, Which, like two spirits, do suggest me still:

The better angel is a man right fair,

The worser spirit a woman coloured ill.

To win me soon to hell my female evil

Tempteth my better angel from my side, And would corrupt my saint to be a devil, Wooing his purity with her foul pride;

And whether that my angel be turned fiend

Suspect I may, yet not directly tell;

But being both from me both to each friend, I guess one angel in another's hell.

Yet this shall I ne'er know, but live in doubt,

Till my bad angel fire my good one out.

8 A tradução de Ramos é comumente vista como a primeira grande tradução dos Sonetos no Brasil, um trabalho precursor "dos congêneres que, depois dele, apareceram no Brasil e em Portugal” (RAMOS, [1970], p. 5). 
O soneto 144 consiste num dos poemas mais notórios da seqüência, por apresentar a conjunção (negativa para o eu-lírico) entre o que parece claramente ser o "belo jovem" e a "dama morena" - os dois amores nutridos pelo poeta de modos distintos. Uma relação maniqueísta subjaz a todo o poema, pois, segundo Duncan-Jones em nota (Shakespeare, 1997, p. 402), um anjo bom e um mal competem pela posse da alma de um homem, na qual é estabelecida uma clara diferença entre o anjo personificado pelo "belo jovem", "a man right fair" (em que fair aponta menos para o estereótipo de beleza da época do que para a boa indole do rapaz), e o espírito ruim da "woman coloured ill" (em que a má coloração pode se referir apenas ao aspecto moral da dama, e não necessariamente a sua tez). No esteio desse embate entre o amor físico e o espiritual, é possivel entrever resquícios da tradição teológica cristã muito recorrente na Idade Média, segundo a qual "a mulher era o demônio" responsável pela queda do Éden, permitindo que o verdadeiro e puro amor espiritual pudesse “apenas existir entre homens" (Sonetos, 2003).

Primeiramente, segue-se a tradução de Jerônimo de Aquino (Shakespeare, [1957], p. 309):

Há um amor que me alenta e um que me desespera. Um anjo bom e um mau, que me atuam na vida. Belo amigo, o anjo bom, a minha alma o venera: $O$ anjo mau, mulher escura e corrompida, Para arrastar-me ao inferno, a todo instante insiste Em levar-me o anjo bom, tão assiduo ao meu lado: Em demônio tornar o santo que me assiste, Na alma pura lhe influindo orgulho deslavado. Que feito já demônio o meu amigo esteja Tenho suspeita só, jurar ainda não juro. Amigos entre si, quando ausentes, que seja Inferno um anjo, o mau, para o outro, conjeturo. E conjeturar tal me há de sempre afligir, Enquanto do anjo mau o anjo bom não fugir.

O texto proposto por Aquino não parece aludir em demasia às insinuações sexuais comumente vislumbradas em certos trechos do poema inglês, pois o tradutor prefere empregar ex- 
pressões desprovidas de tais conotações. Assim, Aquino concebe apenas um "belo amigo" no terceiro verso, traduz "foul pride" por "orgulho deslavado" e suaviza a linha 12 em inglês por "Inferno um anjo, o mau, para o outro, conjeturo", em que o genérico "o mau" não está necessariamente ligado às relações amorosas mantidas entre os dois amantes. Exemplo análogo encontra-se no último verso, em que o tradutor expressa "Enquanto do anjo mau o anjo bom não fugir", preferindo utilizar a forma verbal fugir para entrever a liberdade alcançada pelo "belo jovem" em relação à diabólica dama, em vez de denotar a sua expulsão por contaminação venérea.

Em seguida, temos a tradução de Oscar Mendes (Shakespeare, 1969, p. 872):

Dois amores eu tenho, um, conforto, outro angústia, Que, a fantasmas iguais, não cessam de assombrar-se:

$O$ bom anjo homem é de beleza sem par, $O$ mau anjo, mulher de cara mal pintada. Para em breve levar-me ao orco esse demônio Feminino, afastar tenta meu anjo bom, Querendo converter meu santo num demônio, Com orgulho infernal a tentar-lhe a pureza. Que já meu anjo bom demônio se tornou, Poderei suspeitar, mas não posso afirmar; Mas de mim longe estando e sendo os dois, amigos, Acho que esse anjo bom do outro no inferno está:

Mas nunca hei de saber e viverei na dúvida, Até que esse anjo mau meu anjo bom expulse.

A tradução de Mendes parece esboçar as implicações sexuais já mencionadas, como atestam: os versos 8, "Com orgulho infernal a tentar-lhe a pureza"; o verso 12, mesmo que "Acho que esse anjo bom do outro no inferno está" apresente uma inversão confusa em "do outro no inferno" que talvez sirva o propósito de velar uma possível alusão sexual; e o verso 14, igualmente norteado por um hipérbato em "Até que esse anjo mau meu anjo bom expulse”. Aspectos de interesse são captados na linha 2, em que o tradutor se refere a "two spirits do suggest me still" como dois "fantasmas que não cessam de assombrar-me"; no verso 4, 
em que o emprego de "mulher de cara mal pintada" aparenta guiar-se pela metáfora de recursos cosméticos artificiais que mascarem a verdadeira face (e as reais intenções) da dama; no verso seguinte, em que Mendes utiliza o vocábulo formal orco em associação ao inferno (Houaiss; Villar, 2001, p. 2076); e a repetição do item lexical demônio nas linhas 5, 7 e 9, em face de evil-devil-fiend propostos por Shakespeare.

Já o tradutor Péricles E. da Silva Ramos (Shakespeare, [1970], p. 129) propõe a seguinte tradução:

Meus dois amores de consolo e de aflição

Como dois anjos me dominam por igual:

$O$ anjo do bem é um formosíssimo varão,

E uma mulher de cor bem má o anjo do mal.

Para levar-me para o inferno mais depressa

Meu feminino mal tira o anjo do meu lado

E só por transformá-lo em diabo se interessa,

Solicitando-o com um ardor abominado.

Se o anjo se fez demônio, eis ponto alto encoberto:

Bem posso desconfiar, porém não asseguro:

São amigos, e como eu não os vejo perto,

Que um esteja no inferno do outro conjeturo.

Sobre isso viverei em dúvida, porém,

Até que o anjo do mal expulse o anjo do bem.

Ramos esboça uma longa nota explicativa referente à fortuna crítica deste soneto, na qual demonstra sua adesão à idéia de que o poema reforça alusões sexuais. Segundo ele - com base nos trabalhos exegéticos de críticos como Rollins e Theobald -, o vocábulo pride no verso 8 possuiria a conotação de heat ou cio (Ramos, [1970], p. 129), traduzindo a expressão “foul pride" por "ardor abominado". O tradutor ressalta também hell no verso 12 , termo que, em alusão a um conto de Boccaccio no "Decamerão, não oferece obscuridade alguma quanto à sua localização na topografia" feminina (Ramos, [1970], p. 129), e apresenta "Que um esteja no inferno do outro conjeturo"; há ainda a expressão fire out normalmente associada, pelos críticos, à transmissão de uma doença venérea, perante a qual Ramos propõe "Até que o anjo do mal expulse o anjo do bem". Nota-se, na tradução em 
pauta, um claro tom declamativo - perceptivel em especial na escolha apurada de vocábulos, como "formosíssimo varão" por "a man right fair", no verso 3, aspecto possivelmente decorrente da filiação de Ramos com a poesia neoparnasiana da Geração de 45 , imbuída de todo o seu rigor com a forma poética (metro e esquemas rímicos precisos).

Por fim, acrescenta-se à analise o texto de Jorge Wanderley (Shakespeare, 1994, p. 319):

Dois amores, um calmo e um de aflição,

Espiritos que tenho, me influenciam.

É homem, o anjo bom, de alta extração,

E o mau, mulher tisnada em demasia.

A dar-me logo o inferno, o mal-mulher

Tenta o meu anjo bom, logo o retira

E quer que o santo vá demônio, quer

Levar luxúria à graça que o cobrira.

E embora eu pense que o anjo bom bem há-de

Doar-se ao diabo, não sou eu que o diga;

Anjos de mim saidos na amizade,

Um no inferno do outro talvez siga.

Talvez - e sei que a dúvida não cessa-

Até que o anjo mau ao bom despeça.

Wanderley, munido da concepção de que esse soneto é repleto de metáforas ao ato sexual (como ressalta em nota de rodapé à sua tradução): a) afirma explicitamente, nos versos 7 e 8 , que a dama "quer/Levar luxúria à graça que o cobrira"; e b) revela que "o anjo bom bem há-de/Doar-se ao diabo", nas linhas 9 e 10, e que "Um no inferno do outro talvez siga". No último verso, em relação ao qual o tradutor assevera que "fire out pode se referir a que um amante 'atinja' o outro pela contaminação de uma enfermidade venérea, que grassava na sociedade elizabetana" (Wanderley, 1994, p. 319), há a crença de que o anjo mau despeça o anjo bom, ou afaste-o de sua presença em virtude de tal transmissão.

No decorrer do poema podem ser observadas outras escolhas interessantes, como o uso do adjetivo tisnada em referência à dama, o qual, segundo o Dicionário Houaiss (2001, p. 2726), 
denota alguém "que adquiriu tonalidade escura" ou pode aludir simplesmente a diabo, se se considerar o uso informal nas variedades do português do Brasil. No tocante aos epítetos empregados para representarem a figura diabólica, Wanderley aplica tradicionalmente demônio no verso 7 e diabo no verso 9, além de apresentar uma criativa conjunção aliterativa em mal-mulherna linha 5, fator ligado à priorização da musicalidade do poema, tão cara ao tradutor em pauta.

\section{Considerações finais}

Ao término dessa breve reflexão acerca da recepção promovida aos Sonetos de William Shakespeare, tanto no decorrer do eixo temporal (do século XVI à atualidade) quanto do eixo espacial (que se estende pela ponte Inglaterra-Brasil), torna-se possivel constatar como as controvérsias da seqüência continuam a ser alimentadas por gerações de leitores e críticos, o que lhes adere um papel preponderante na formação dessa recepção. Os Sonetos, desde sua primeira publicação em 1609, são freqüentemente vistos como um enigma a ser desvendado, em virtude da aparente incompatibilidade entre a aura de erudição e requinte tradicionalmente vinculada a Shakespeare - enquanto homem e poeta - e a polêmica instaurada, entre outros aspectos, pelo amor incondicional a um jovem rapaz e o desprezo a uma mulher provida de moral duvidosa.

Conforme a discussão anterior atesta, a possivel homossexualidade do bardo inglês perpassa uma questão de caráter politico, em que a manutenção de uma sexualidade socialmente aceitável almeja assegurar igualmente a integridade da cultura que sustenta a imagem do poeta e a divulga ao resto do mundo. É por essa razão que os críticos buscaram - até o advento do século XX e a maior receptividade para leituras homoeróticas velar as possiveis alusões comprometedoras e aderir uma heterossexualidade ao corpo da seqüência, ou mesmo mascarar sua preferência e admiração pelos Sonetos mediante o temor de ter sua sexualidade equiparada àquela polemizada pelo cânone literário ocidental. 
Neste trabalho, formulei a hipótese segundo a qual toda a polêmica gerada em torno dos poemas shakesperianos tenha influenciado sua recepção também no Brasil, se se levar em conta o considerável espaço de tempo transcorrido entre as primeiras traduções em lingua portuguesa das peças do bardo (início do século XX) e o texto parcial dos Sonetos assinado por Péricles E. da Silva Ramos em 1953. Além disso, a crítica brasileira volta praticamente toda a sua atenção ao legado teatral do Poeta Nacional da Inglaterra, fato passível de observação em virtude da escassa quantidade de resenhas críticas em jornais ou revistas e da ausência de volumes, no panorama brasileiro, dedicado a esse assunto. Nesse esteio, torna-se possivel ressaltar semelhante tratamento no universo acadêmico brasileiro, também dominado pela dramaturgia do bardo (como em Vollet, 1998).

Com base na breve análise do Soneto 144 exposta aqui um dos mais polêmicos da seqüência por esboçar um aspecto maniqueísta entre os dois amores controversos do eu-lírico -, nota-se que os tradutores investigados aderem às possíveis alusões sexuais do poema (com exceção de Jerônimo de Aquino), à maneira de renomados trabalhos de exegese existentes; todavia, suas opções lexicais parecem atenuar a forte e controversa carga semântica presente no texto em inglês. Claramente, tais escolhas lexicais são igualmente provocadas por outros fatores, como a imposição dos sistemas de metrificação e rimas utilizados pelo tradutor, mas a atenuação ainda prevalece. Aquino propõe um texto altamente refinado e provido de itens lexicais que dificilmente apontam para relações sexuais entre os dois amores do eu-lírico; Mendes, por sua vez, opta pelo verso alexandrino clássico de 12 sílabas desprovido de esquema rímico, o que lhe possibilita maior liberdade quanto ao emprego de um vocabulário acessível e à beira do prosaico; Ramos, poeta vinculado à geração pejorativamente rotulada de neoparnasiana, apresenta um tom eloqüente e declamativo que exige um léxico mais apurado e de maior sutileza; Wanderley - numa atitude um pouco discrepante da dos demais tradutores - utiliza-se de vocábulos da variedade padrão contemporânea brasileira com o intuito de melhor esboçar (e não de velar) as alusões sexuais do soneto, em face de sua adesão expressamente confirmada nas notas explicativas. 
Em suma, todas essas escolhas, em suas semelhanças e diferenças, apontam para concepções próprias dos tradutores relativas à natureza da tradução de poesia - que se espelham, de forma explícita ou não, em seus textos. Tais noções se aliam, no presente caso, à própria condição do que significa trazer a obra shakesperiana ao Brasil, em distintos momentos no tempo, e de que maneira ela deve ser apresentada ao grande público-leitor. Enfim, cabe ao tradutor realizar sua leitura de um texto com base em sua formação intelectual e na perspectiva erigida pelas fronteiras de sua comunidade. Em se tratando de uma das inúmeras facetas da obra de William Shakespeare, sua função não se restringe a perpetuar as antigas polêmicas ou a buscar assegurar os significados tradicionalmente associados ao bardo, pois, mesmo pautando-se no legado acumulado há séculos, visa a atribuir-lhe um novo sopro de vida.

\section{Referências bibliográficas}

DUNCAN-JONES, Katherine (1997). Introduction. In: SHAKESPEARE, William. Shakespeare's Sonnets. Ed. Katherine Duncan-Jones. London: Arden Shakespeare, p. 1-105.

EAGLETON, Terry (2001). A ascensão do inglês. Teoria da literatura: uma introdução. Trad. Waltensir Dutra. 4 ed. São Paulo: Martins Fontes, p. 23-73.

FISH, Stanley (1980). Is there a text in this class? . Is there a text in this class?: the authority of interpretive communities. Cambridge/London: Harvard University Press, p. 303-321.

GOMES, Eugênio ([1961]). Shakespeare no Brasil. Rio de Janeiro: Ministério da Educação e Cultura.

GUEIROS, Nehemias (1975). Mistério do soneto shakespeariano. In: SHAKESPEARE, William. 24 Sonetos. Trad. Ivo Barroso. 2 ed. Rio de Janeiro: Nova Fronteira, p. 7-52.

HELIODORA, Bárbara (1997). Falando de Shakespeare. São Paulo: Perspectiva.

HOLDERNESS, Graham (1988). Bardolatry: or, The cultural materialist's guide to Stratford-upon-Avon. The Shakespeare myth. Manchester: Manchester University Press, p. 2-15. 
HOUAISS, Antônio; VILLAR, Mauro de S. (ed.) (2001). Dicionário Houaiss da lingua portuguesa. Rio de Janeiro: Objetiva.

JUNQUEIRA, Ivan (1991). Shakespeare em sonetos. O Globo, Rio de Janeiro, 17 nov..

MARGOLIES, David (1988). Teaching the handsaw to fly: Shakespeare as a hegemonic instrument. In: HOLDERNESS, Graham (ed.). The Shakespeare myth. Manchester: Manchester University Press, p. 4253.

MENDES, Oscar. Nota introdutória (1969). In: SHAKESPEARE, William. Obra completa. Rio de Janeiro: Companhia José Aguilar, v. 3, p. 735-737.

RAMOS, Péricles E. da S ([1970]). Introdução. In: SHAKESPEARE, William. Sonetos. Trad. Péricles Eugênio da Silva Ramos. 2 ed. Rio de Janeiro: Ediouro, p. 9-41.

SHEPHERD, Simon (1988). Shakespeare's private drawer: Shakespeare and homosexuality. In: HOLDERNESS, Graham (ed.). The Shakespeare myth. Manchester: Manchester University Press, p. 96-110. SHAKESPEARE, William ([1957]). Sonetos. Trad. Jerônimo de Aquino. São Paulo: Melhoramentos.

. (1969). Sonetos. Trad. Oscar Mendes. Obra completa. Rio de Janeiro: Companhia José Aguilar, v. III, p. 815-877.

. ([1970]). Sonetos. Trad. Péricles Eugênio da Silva Ramos. 2 ed. Rio de Janeiro: Ediouro.

. (1994). Sonetos. Trad. Jorge Wanderley. 2 ed. Rio de Janeiro: Civilização Brasileira.

SONETOS. Disponível em: <www.shakespeares-sonnets.com>. Acesso em: 27 nov. 2003.

VOLLET, Neuza L. R. (1998). Nobreza vs obscenidade em traduções brasileiras de Hamlet: uma reflexão sobre as relações possiveis entre os tradutores e seu autor. TradTerm, São Paulo, v. 5, n. 2, p. 7196.

WANDERLEY, Jorge (1994). Introdução. In: SHAKESPEARE, William. Sonetos. Trad. Jorge Wanderley. 2 ed. Rio de Janeiro: Civilização Brasileira, p. 9-23. 